\title{
PENGARUH PERSEPSI TENTANG PROFESI SEBAGAI PENDIDIK TERHADAP MOTIVASI KERJA DAN KINERJA GURU
}

\author{
Ayu Mardiyani \\ SDN Sawojajar 4. Jl. Simp. Ranugrati Selatan III/114 \\ Sawojajar Kedungkandang \\ e-mail: ayumardiyani888@gmail.com
}

\begin{abstract}
The aims of this study are to describe: the teachers' perception as educator; the level of work motivation and teacher performance; the effects of perception on work motivation and performance; the effects of work motivation on the teacher performance; and the indirect effect of perception on the teacher performance. This study used a quantitative approach with a correlational multivariate design. The sample of study consisted of 109 teachers that were selected through the proportional random sampling technique. Results indicate: the educator role was moderately perceived by teachers; teachers' work motivation and the performance were at a moderate level; the perception significantly influenced work motivation. However, there was no significant direct effects of perception on the level of teacher performance. Their effects were meadiated by the increased motivation.
\end{abstract}

Keywords: perception, motivation, teacher, performance.

\begin{abstract}
Abstrak: Tujuan penelitian ini untuk mendeskripsikan: persepsi guru sebagai pendidik; tingkat motivasi kerja dan kinerja guru; pengaruh persepsi terhadap motivasi kerja dan kinerja; pengaruh motivasi kerja terhadap kinerja; dan pengaruh tidak langsung persepsi terhadap kinerja. Penelitian ini menggunakan pendekatan kuantitatif dengan desain correlational multivariate. Sampel penelitian ini terdiri dari 109 orang guru yang ditetapkan menggunakan teknik proportional random sampling. Hasil penelitian menunjukkan: persepsi guru sebagai pendidik dalam tingkatan sedang; motivasi kerja dan kinerja gurudalam tingkatan sedang; terdapat pengaruh signifikan persepsi terhadap motivasi kerja. Walaupun, tidak terdapat pengaruh signifikan persepsi terhadap kinerja secara langsung. Terdapat pengaruh persepsi terhadap kinerja guru yang dimediasi oleh motivasi kerja.
\end{abstract}

Kata Kunci: persepsi, motivasi, guru, kinerja.

Guru sebagai individu memiliki perbedaan satu dengan yang lain dalam cara berfikir, sudut pandang dan berpendapat karena perbedaan rangsangan terhadap suatu obyek berbeda (Toha, 2003). Hal tersebut dikarenakan setiap obyek dipersepsikan dengan berbeda pada setiap individu. Dalam kehidupan sehari-hari pola pikir, tingkah laku dan penyesuaian diri guru ditentukan oleh bagaimana cara yang bersangkutan mempersepsikan fenomena dengan dukungan alat inderanya. Persepsi individu ini diikuti oleh daya tangkap dan penafsiran informasi yang diperoleh panca indera secara langsung membentuk kesan yang berbeda pula antar individu (Ling \& Catling, 2012).

$$
\text { Persepsi masing-masing guru yang }
$$

berbeda, sehingga motivasi kerja yang dimiliki juga berbeda. Perbedaan tersebut tidak hanya berpengaruh terhadap motivasi kerja, tetapi juga kinerja setiap guru. Seorang guru yang memiliki persepsi baik tentang profesinya maka akan baik pula motivasi kerja serta kinerjanya dalam mencapai tujuan pembelajaran. Namun dalam kenyataan sehari-hari masih ditemukan adanya gejala antara lain: (1) kurangnya kemauan guru menciptakan pembelajaran yang variatif, (2) masih banyaknya peserta didik yang belum mampu memperhatikan apa yang dijelaskan oleh guru, (3) adanya guru yang belum memiliki motivasi kerja dan kinerja yang tinggi terhadap makna pembelajaran sebenarnya. Dari berbagai gejala tersebut maka dilaksanakan penelitian lebih lanjut dengan mengeksplorasi keterkaitan 
persepsi, motivasi kerja dan kinerja guru.

Persepsi adalah proses seseorang menjadi lebih sadar dalam berbagai hal yang ada di lingkungannya melalui indera-indera yang dimiliki, pengetahuan lingkungan yang didapatkan melalui hasil pengelolahan alat indera yang digunakan (Kartono \& Gulo, 2003). Proses persepsi dinyatakan oleh (Sugihartono, dkk, 2007) bahwa persepsi merupakan proses untuk menerjemahkan atau menginterpretasikan rangsangan yang diterima oleh panca indera. Terdapat penerapan perundangan yang mengatur hak dan kewajiban guru untuk menciptakan persepsi tentang profesi pendidik. Undangundang yang mengatur hak dan kewajiban guru sebagai jaminan baik pemenuhan hak kehidupan guru (kesejahteraan, penghargaan dan lain-lain)

Uno (2011) motivasi adalah kekuatan dari dalam maupun luar seseorang yang mampu mendorong seseorang dalam mencapai tujuan tertentu yang telah ditetapkan sebelumnya. Motivasi terbagi menjadi dua macam yaitu motivasi intrinsik dan motivasi ekstrinsik. Motivasi instrinsik merupakan perlibatan diri kedalam sebuah aktivitas yang memiliki nilai/ manfaat (aktivitas tersebut merupakan sebuah tujuan akhir) (Schunk dkk, 2012). Faktor-faktor motivasi yang timbul dari dirinya sendiri yaitu: keinginan untuk berprestasi, keinginan untuk maju dan keinginan memiliki kehidupan pribadi. Motivasi ekstrinsik merupakan kegiatan belajar yang tumbuh dari dorongan dan kebutuhan diluar diri seseorang (Yamin, 2008). Faktorfaktor ekstrinsik seorang guru yang akan mempengaruhi semangatnya dalam bekerja, sebagai berikut: pekerjaan itu sendiri, status kerja, tempat pekerjaan, keamanaan pekerjaan, gaji atau penghasilan yang layak, pengakuan dan penghargaan, kepercayaan melakukan pekerjaan, serta kebijaksanaan administrasi.

Kinerja guru merupakan tindakan nyata yang ditampilkan oleh seorang guru sebagai prestasi kerja yang sesuai dengan standar yang ditetapkan dan sesuai dengan perannya dalam proses pembelajaran (Rivai, 2004). Faktor kemampuan (ability) dan faktor motivasi (motivation) merupakan faktor yang mempengaruhi pencapaian kinerja (Mangkunegara, 2010). Faktor-faktor kinerja guru juga dipengaruhi oleh faktor internal dan faktor eksternal. Faktor internal kinerja guru merupakan faktor yang datang dari dalam diri seorang guru sehingga dapat mempengaruhi kinerjanya. Selain itu, faktor eksternal kinerja guru merupakan faktor yang datang dari luar diri seorang diri sehingga mampu mempengaruhi kinerja (Barnawi \& Arifin, 2012).

\section{METODE}

Penelitian ini menggunakan pendekatan kuantitatif, karena informasi serta data dokumen yang diperoleh diwujudkan dalam bentuk angka serta analisis statistik. Desain correlational multivariate digunakan dalam penelitian ini. Sampel yang digunakan adalah 109 orang dari jumlah populasi 150 orang yang terdiri dari para guru. Teknik analisis yang akan digunakan adalah (1) teknik analisis deskriptif; (2) pengujian data melalui uji normalitas; dan (3) analisis jalur (path analysis). Model analisis jalur digunakan agar dapat melukiskan adanya hubungan antara variabel eksogen yaitu $X$ (persepsi), dan variabel endogen Y1 (motivasi kerja) dan Y2 (kinerja guru). Setiap variabel eksogen maupun endogen digambarkan dalam bentuk segitiga. Dapat diartikan bahwa hubungan $\mathrm{X}$ terhadap $\mathrm{Y} 1, \mathrm{X}$ terhadap $\mathrm{Y} 2$, dan disebut pengaruh langsung jika dari Y1 ke Y2, sedangkan disebut pengaruh tidak langsung jika X terhadap Y2 melalui Y1.

\section{HASIL}

Tingkat Persepsi tentang Profesi sebagai Pendidik

Tabel 1 Analisis Deskriptif Variabel Persepsi Tentang Profesi Pendidik

\begin{tabular}{lrrr}
\hline Interval & Kualifikasi & Frekuensi & Percent \\
\hline $114-128$ & Rendah & 18 & 16,5 \\
$129-143$ & Sedang & 62 & 56,9 \\
$\geq 144$ & Tingg & 29 & 26,6 \\
\hline Total & & 109 & 100
\end{tabular}

Pengorganisasian pondok pesantren dan madrasah menjadi satu kesatuan dengan yayasan lembaga pendidikan ma'arif NU kota Blitar. Pengelolaan pesantren dan madrasah di MAM NU Kota Blitar berupa struktur organisasi dan pembagian tugas masing-masing serta tanggungjawab yang sesuai kedudukn dan wewenang. Sehingga setiap kegiatan 
dpat dikoordinasikan dengan baik. Tugas dan wewenang ustadz/ustadzah madrasah sudah tertulis dalam tugas pokok dan fungsinyanya. Pengasuh pondok pesantren bertugas mengatur seluruh kegiatan yang terlaksana di pondok pesantren. Selain itu, memimpin kegiatan evaluasi dan mengontrol seluruh kegiatan. Pengasuh dibantu oleh pendamping pondok pesantren guna untuk membangunkan santri pagi hari, mengurusi santri yang sakit, mengontrol kegiatan santri, mengobrak-obrak santri yang malas, dan memberi hukuman bagi santri yang melakukan pelanggaran sebelumnya sudah dikoordinasikan kepada pengasuh. Di dalam pondok pesantren, juga terdapat ketua. Ketua di sini bertugas menghandel semua kegiatan santri yang kemudian dibagi ke masing-masing devisi. Akan tetapi, jika sudah masuk pendidikan formal maka itu tugas dari pihak madrasah. Keberadaan santri merupakan tanggung jawab para pengasuh. Akan tetapi, pada saat pembelajaran di madrasah formal penanggung jawabnya yaitu pihak madrasah. Sebaliknya, pada saat santri sudah berada di lingkungan pondok pesantren merupakan tanggung jawab pengasuh. Meskipun demikian kedua pihak madrasah dan pondok pesantren tetap saling berkoordinasi untuk mengawasi para santri.

Pembelajaran di MAM NU Kota Blitar terbagi menjadi 2 yaitu: pertama, pembelajaran formal dimulai jam 07.00 sampai 12.00 kemudian dilanjutkan pembelajaran sore pada jam 13.20 samapai 16.00. Kedua, pembelajaran diniyah dimulai pukul 18.20 sampai 20.00. Pembelajaran diniyah pada malam hari dibagi menjadi dua yaitu mengaji kitab kuning dan A-Quran dengan metode Utsmani. Pembelajaran ini ada dua tingkatan yaitu ula dan wustho. Kegiatan ini dilaksanakan pada hari Jum'at sampai hari Rabu dengan pembagian 3 hari mengaji kitab dan 3 hari mengaji Al-Qur'an. Sedangkan pada hari Kamis kegiatan bersama membaca do'a tahlil, istighosah, diba', dan lain sebagainya.diselasela kegiatan santri yang padat terdapat jadwal makan yang sudah diatur 3 kali sehari. Jadwal pengambilan makan pagi dimulai jam 06.00 sampai 06.30, makan siang dimulai jam 12.00 sampai jam 13.00, dan makan sore dimulai pukul 16.00 sampai 18.00 . Apabila terdapat santri yang tidak bisa mengambil makan sesuai jadwal maka harus lapor kepada petugas. Sistem distribusi makan dibagi ke tiga titik untuk menghindari antrian panjang. Santri dipersilakan mengambil nasi sesuai keinginan sedangkan lauknya dibagikan oleh petugas untuk menghindari santri yang mengambil jatah lebih. Bagi santri yang melakukan pelanggaran akan mendapat sanksi dari pengurus. Sanksi tersebut dapat berupa teguran, membersihkan area pondok pesantren, membersihkan kamar mandi, dan mencuci pakaian.

Kegiatan evaluasi atau pengawasan di MAM NU Kota Blitar ditujukan agar pengelolaan organisasi sesuai dengan tujuan perencanaan yang telah ditetapkan sebelumnya. Evaluasi di MAM NU Kota Blitar dibagi ke masing-masing penanggungjawab, namun ada satu kegiatan evaluasi yang dilaksanakan dalam satu yayasan. Pertama, evaluasi pondok pesantren dilaksanakan oleh pengasuh beserta pendamping dan ketua seminggu sekali. Kegiatan ini, evaluasi kegiatan yang sudah terlaksana dan yang dilaksanakan. Kedua, evaluasi pengurus madin, dilaksanakan seminggu sekali setiap hari Rabu, pembahasan mengenai keterlaksanaan kegiatan madin dan kendala yang ditemui. Ketiga, evaluasi para civitas akademik madrasah setiap sebulan sekali. Komponen yang dievaluasi di madrasah bersifat totalitas yaitu pertama kegiatan santri mulai dari bangu sampai tidur lagi, sholat tahajud, sholat subuh, sholat dhuha, keteraturan makannya, ketertiban masuk kelas, KBM, dan tadarus. Ketiga, realisasi program madrasah dan evaluasi KBM dalam satu ulan yang sudah terlaksana atau kegiatan lainnya.

\section{PEMBAHASAN}

Perencanaan layanan khusus pondok pesantren dilakukan setiap awal tahun pelajaran baru. Pada kesempatan ini membahas kegiatan apa yang akan dilaksanakan dan bagaimana cara mencapainya. Penentuan kegiatan di MAM NU Kota Blitar ini dibentuk dalam kegiatan workshop yang melibatkan seluruh pihak Yayasan Ma'arif yang bekerja didalamnya. Kegiatan ini dipimpin lagsung oleh direktur perguruan ma'arif. Menurut Aryawiga (2012) yang dimaksud perencanaan di sini menitikberatkan pada usaha untuk menyeleksi dan menghubungkan sesuatu dengan kepentingan masa yang akan datang serta usaha untuk mencapainya. Semua program kegiatan 
dari masing-masing satuan tidak serta merta diterima begitu saja. Akan tetapi dibicarakan pada saat workshop dan akan direvisi bersama pimpinan serta mendapatkan masukan/saran dari berbagai pihak yang mengikuti kegiatan workshop tersebut. Kemudian, jadwal untuk para santri disesuaikan dengan jadwal tahun sebelumnya namun juga ada beberapa yang perlu direvisi. Mulai jadwal tidur santri, makan, ibadah, belajar dan kegiatan lainnya baik saat dimadrasah maupun saat berada dipondok pesantren. Selain itu, hubungan personal pondok pesantren, madrasah dengan masyarakat juga dibutuhkan untuk memupuk rasa persaudaraan antar sesama dalam hidup bermasyarakat. Bentuk kegiatan tersebut biasanya dilakukan oleh warga pondok pesantren atau madarsah apabila ada warga sekitar yang terkena musibah kematian, sebagian dari mereka ikut mengurus jenazah.

Bentuk pengorganisasian layanan khusus pondok pesantren di MAM NU Kota Blitar merupakan pembagian anggota terhadap bidang tugas masing-masing sehingga tujuan dari lembaga dapat tercapai. Pengorganisasian diawali dengan mengorganisir person untuk mengisi jabatan-jabatan yang ada. Anggota yang sudah ditetapkan dalam jabatannya akan dibagi ke masing-masing job description. Sruktur organisasi yang ada di Yayasan Lembaga Pendidikan Ma'arif Kota Blitar dimulai dari kedudukan tertinggi yaitu, PCNU Kab/Kota Blitar, BPPAB/LP Ma'arif NU, Direktur/ Pimpinan Ponpes, Wakil direktur, Pengasuh Asrama, Kepala Madin, Kepala Madrasah, Kepala Poskestren serta Kopontren. Hal ini sesuai dengan pernyataan yang dikemukakan oleh Hasibuan (dalam Sujarwo, 2012:33) yang dimaksud pengorganisasian adalah suatu proses menentukan, mengelompokkan dan pengaturan secara bersama dalam suatu kegiatan untuk mencapai tujuan, menentukan orang-orang yang akan melakukan aktivitas atau kegiatan, menyediakan alat yang diperlukan, menetapkan wewenang yang dapat didelegasikan kepada setiap individu yang akan melaksanakan aktivitas atau kegiatan.

Pelaksananaan layanan khusus pondok pesantren di MAM NU Kota Blitar berlangsung sesuai program yang telah direncanakan pada awal tahun pelajaran baru. Baik program kerja madrasah maupun asrama dapat dilaksanakan dengan baik. Jadwal yang diterapkan untuk santri baru pun dapat diikuti oleh mereka. Kegiatan pembelajaran pagi yang dimulai jam 07.00 sampai jam 12.00, pembelajaran sore jam 13.20 sampai jam 16.00, dan pembelajaran malam jam 18.30 sampai jam 20.00. pembelajaran pagi hari sudah dapat dikatakan tertib karena seluruh santri dapat mengikuti pembelajaran dengan baik dan tidak ada yang berkeliaran diluar kelas ketika jam pelajaran berlangsung. Kondisi ini sangat jauh berbeda dengan pelaksanaan pembelajaran pada malam hari. Karena pada pembelajaran malam hari masih ditemukan santri yang tidak ikut belajar dan mereka juga berkeliaran sehingga mengganggu santri lain yang sedang belajar. Para pendamping sudah berusaha menegur dan memperingatkan mereka agar mengikuti kelas. Namun, para santri masih saja ada yang mengindahkan teguran tersebut. Hal ini sesuai dengan pendapat Westra (dalam Rahardjo Adisasmita, 2011) pelaksanaan yaitu sebagai usaha-usaha yang dilakuakan untuk melaksanakan semua rencana dan kebijaksanaan yang telah dirumuskan dan ditetapkan dengan melengkapi segala kebutuhan alat-alat yang diperlukan, siapa yang akan melaksanakan, dimana tempat pelaksanaannya dan kapan waktu dimulainya. Selain kegiatan pembelajaran, kegiatan lain yang sudah dapat terlaksana dengan baik yaitu jadwal makan santri. Setiap hari santri mendapat makan 3 kali yaitu pagi, siang dan malam. Hal ini juga merupakan tugas dari seorang pendamping asrama yaitu menyediakan makan/ minum, mengemasi alat-alat dan sisa makanan, mencuci piring, sendok, gelas, menyimpan sisa makanan, serta mengantar makanan/minuman jatah penghuni yang sakit (Kusmintardjo, 1992:13-18).

Kegiatan pengawasan yang dilakukan di MAM NU Kota Blitar dilakukan dalam waktu 24 jam. Baik pengasuh maupun pendamping selalu mengawasi seluruh kegiatan para santri mulai dari bangun sampai tidur lagi. Sehingga para santri dapat dikendalikan dengan mudah. Pengawasan layanan khusus pondok pesantren di MAM NU Kota Blitar merupakan kegiatan evaluasi, menilai dan mengukur pelaksanaan, apakah telah sesuai dengan tujuan yang telah ditetapkan sebelumnya pada perencanaan. Pengawasan dilakukan oleh seluruh civitas akademik yayasan yang dilakukan satu bulan sekali. 
Pihak yang melakukan penilaian atau evaluasi secara langsung adalah pimpinan yayasan untuk keseluruhan. Sedangkan dalam lingkup madrasah dipimpin oleh kepala madrasah, lingkup pondok pesantren dipimpin oleh pengasuh, serta lingkup madin dipimpin oleh kepala madin. Pelaksanaan evaluasi dilaksanakan sesuai jadwal yang sudah ditentukan. Evaluasi terhadap program kerja disesuaikan dengan komponen-komponen yang dibutuhkan disetiap lembaga. Di MAM NU Kota Blitar, program yang dievaluasi bersifat menyeluruh sesuai dengan keadaan yang ada. Sehingga memudahkan warga madrasah dalam mengevaluasi, kegiatan apa yang sudah tercapai dan terlaksana dan kegiatan apa yang belum dapat dilaksanakan. Hal ini sesuai dengan pendapat Sujarwo (2012:62) fungsi evaluasi sebagai serangkaian kegiatan yang sistematis yang dilakukan dalam rangka untuk mengetahui apakah suatu kegiatan pendidikan telah berjalan sesuai dengan tujuan yang telah ditetapkan atau belum. Pelaksanaan proses evaluasi tidak hanya dilakukan sekali saja, tapi harus sering dilakukan (bertahap) sesuai lamanya kegiatan dilakukan. Evaluasi juga dilaksanakan secara kontinyu dan dilaksanakan bersama dengan melibatkan seluruh warga madrasah dan pondok pesantren.

\section{SIMPULAN DAN SARAN}

\section{Simpulan}

Berdasarkan hasil penelitian dan pembahasan tersebut, dapat disimpulkan bahwa manajemen layanan khusus pondok pesantren di MAM NU Kota Blitar yaitu pertama perencanaan dilakukan pada awal tahun pelajaran baru. Kegiatan tersebut dilakukan dalam bentuk workshop yang diikuti oleh pimpinan yayasan, kepala madrasah, pengasuh asrama, kepala madin serta ustadz dan ustadzah. Selain itu, juga menyusun jadwal harian santri. Kedua, pengorganisasian dilakukan dengan menyusun struktur organisasi madrasah, yang meliputi Ketua yayasan, kepala madrasah, komite, pembina, kaur TU, waka, dan dewan ustadz dan ustadzah. Selain itu, juga terdapat job description masing-masing jabatan, yang sudah tertulis di Surat Keputusan. Ketiga, pelaksanaan terdiri dari implementasi program kerja yang telah direncanakan, baik program kerja pendidikan formal dan nonformal yang dilaksanakan secara beriringan. Kegiatan pendidikan formal yaitu pembelajaran pagi hingga siang hari, sedangkan non formal dilaksanakan pada malam hari. Implementasi jadwal harian santri yang sudah disusun pada awal tahun pelajaran baru. Sistem pendistribusian makan untuk para santri serta jadwal pengambilannya. Keempat, pengawasan lebih mengarah pada kegiatan evaluasi programprogram yang dilakukan oleh seluruh ustadz dan ustadzah yang dipimpin langsung oleh pimpinan yayasan. Waktu pelaksanaan rapat evaluasi madrasah dilakukan satu bulan sekali, madin satu minggu sekali dan ponpes satu minggu sekali. Komponen-komponen yang dievaluasi meliputi ketertiban dan kedisiplinan mulai santri bangun tidur sampai santri tidur kembali, dan ketercapaian program pendidikan.

\section{Saran}

Berdasarkan kesimpulan tersebut, maka peneliti memberikan saran terhadap beberapa pihak, yaitu pertama Kepala MAM NU Kota Blitar, sebaiknya juga turut serta dalam mengelola Ponpes sehingga dapat mengetahui kekurangan yang dimiliki di ponpes. Kedua, Kepala Madrasah Diniyah MAM NU Kota Blitar, sebaiknya semua kelas madin dilaksanakan di ruang kelas dan tidak diasrama. Karena, jika terdapat santri yang tidak mengaji tidak akan mengganggu pandangan atau konsentrasi santri yang sedang madin. Ketiga, Pengasuh Asrama MAM NU Kota Blitar, memperbarui kembali tata tertib yang ada di asrama dan sanksi-sanksi dipertegas agar para santri jera. Keempat, Pendamping Asrama MAM NU Kota Blitar, lebih meningkatkan kedisiplinan untuk santri yang tidak mengikuti kegiatan madin dan memberikan sanksi yang tegas supaya santri yang lain tidak mengikuti. Kelima, Peneliti lain diharapkan dapat melanjutkan penelitian sejenis pada berbagai aspek lain, dan penelitian ini dapat dijadikan sebagai bahan rujukan tanpa melupakan nilai keaslian dalam penelitian di bidang manajemen layanan khusus pondok pesantren.

\section{DAFTAR RUJUKAN}

Adisasmita, R. 2011. Pengelolaan pendapatan dan Anggaran Daerah. Yogyakarta: Graha Ilmu.

Aryawiga. 2012. Manajemen Layanan Khusus Sekolah. (Online), (http://aryawiga.wordpress. com/2012/02/17/manajemen-layanan-khusus- 
sekolah/), diakses pada 2 April 2015.

Kusmintardjo. 1992. Pengelolaan Layanan Khusus di Sekolah (Jilid II). Malang: IKIP Malang.

Moleong, L. 2005. Metodologi Penelitian Kualitatif: Edisi Revisi.Bandung: PT Remaja Rosdakarya.

Triwiyanto. T. 2015. Pelaksanaan Monitoring, Evaluasi, dan Pelaporan Untuk Penilaian Kinerja Manajerial Kepala Sekolah. Cakrawala Pendidikan. XXXIV (1): 67-77.

Ulfatin, N. 2013. Metodologi Penelitian Kualitatif di Bidang Pendidikan: Teori dan Aplikasinya. Malang: Banyumedia.

Wiyono, B.B. 2007. Metodologi Penelitian: Pendekatan Kualitatif, Kuantitatif, dan Action Research (Burhanuddin, Ed). Malang: Fakultas Ilmu Pendidikan Universitas Negeri Malang. 